\title{
IMPLEMENTATION OF CHARACTER EDUCATION IN BUILDING SCHOOL CULTURE
}

\author{
Aunurrahman \\ Fakultas Keguruan dan Ilmu Pendidikan Untan \\ Email: aunuruntan@gmail.com
}

\begin{abstract}
This research aims to find out about the implementation of character education in building school culture. The research was conducted at elementary schools in Sambas Regency with representation of a number of elementary schools from several sub-districts in Sambas Regency. The data were collected by combining quantitative and qualitative approaches, with data collection techniques using interviews, FGDs and questionnaires. The qualitative data analysis used the interactive analysis technique of Miles and Huberman, while the quantitative data analysis used factor analysis and percentage. The results showed that in general the implementation of character education in building school culture in the Sambas Regency elementary schools in several dimensions was well implemented. However, in certain parts, especially in the dimensions of the program and evaluation, it has not been fully actualized as expected. Meanwhile, school culture as a whole has developed well, especially in the dimensions of disciplinary culture, exemplary culture and culture of order and cleanliness. These three dimensions of culture are the fundamental foundation of building school culture. In the disciplinary culture dimension, the biggest contribution is to hold the midday prayer in congregation, while in the dimension of order and cleanliness culture, the biggest contribution is to hold a school ceremony.
\end{abstract}

Key words: Character Education, School Culture

\section{PENDAHULUAN}

Pembentukan karakter individu memiliki kedudukan yang sangat penting, karena di samping diperlukan untuk pengembangan pribadi yang bersangkutan, karakter individu juga akan memberikan sumbangan besar terhadap pembentukan karakter lingkungan, masyarakat dan bangsa yang bermartabat serta menjadi faktor penting bagi proses percepatan pembangunan suatu bangsa. Masyarakat yang mayoritas berkarakter negatif tidak mampu membangun peradaban, apalagi menjadi masyarakat yang berperadaban tinggi. Karena karakter negatif yang mereka lakukan menghambat bekerja- sama antara internal dan eksternal, tidak dapat dipercaya, begitu juga tidak rajin, tidak punya etos kerja dan lain-lain yang akan membuat pembangunan peradaban tidak dapat diwujudkan (Soedarsono, 2009). Padahal sesungguhnya dengan karakter yang baiik memberikan dampak yang psotif terhadap berbagai dimensi pada apeserta didik. Hasil penelitian yang dilakukan Maunah (2015: 94), dengan karakter terbukti memberikan dampak positif bagi siswa terhadap beberapa hal; (1) tumbuhnya motivasi untuk menjadi lebih baik, (2) tidak suka berbohong, (3) respek terhadap orang tua dan mencintai 
sesama, (4) berterima kasih atas sesuatu yang diterima, (4) menghormati sesama, (5) semakin dapat mengapresiasi hasil kerja sama, (6) melatih jiwa kepemimpinan, (7) terbiasa lebih mandiri, penduli terhadap lingkungan, dan (8) terbiasa membantu sesama teman.

Fenomena semakin melemahnya karakter dapat dilihat dengan mudah baik secara langsung dalam keseharian kehidupan bermasyarakat, maupun melalui berbagai media. Fenomena ini juga menyentuh kehidupan sekolah, khususnya terjadi pada para siswa di berbagai jenjang dan satuan pendidikan semakin menunjukkan peningkatan pada beberapa waktu belakangan ini. Dalam kondisi ini dipandang sangat penting program penguatan metodologi dan kurikulum dengan cara menyempurnakan kurikulum dan metode pembelajaran aktif berdasarkan nilai-nilai budaya bangsa untuk membentuk daya saing dan karakter bangsa. Implementasi kebijakan ini adalah bagaimana mengintegrasikan Pendidikan Budaya dan Karakter Bangsa dalam Pendidikan (Kemendiknas, 2011).

Pembentukan karakter peserta didik tidak mungkin dapat dilakukan secara sesaat dan parsial, akan tetapi harus dilakukan dalam kerangka program yang terencana, sistematik, terarah serta berkelanjutan dalam rentang waktu yang panjang, baik melalui proses belajar maupun di luar kegiatan pembelajaran di kelas. Melalui proses pembelajaran dapat dilakukan pada semua bidang studi atau mata pelajaran, termasuk bidang studi eksak. Hasil penelitian Ayi (2018), menemukan bahwa penanaman nilai-nilai karakter secara nyata dapat dikembangkan melaui proses pembelajaran Fisika. Demikian pula hasil penelitian yang dikemukakan oleh Fauzi, Zainudin \& Rosyid (2018: 83) mengungkapkan bahwa penanaman karakter siswa terbukti efektif melalui pengembangan metode pembelajaran discovery.

Dalam organisasi sekolah, pada hakikatnya terjadi interaksi antar individu sesuai dengan peran dan fungsi masing-masing dalam rangka mencapai tujuan bersama. Tatanan nilai yang telah dirumuskan dengan baik berusaha diwujudkan dalam berbagai perilaku keseharian melalui proses interaksi yang efektif. Kekeliruan yang amat sering kita lakukan adalah pembiasaan-pembiasaan yang dilakukan secara tidak konsisten dan tidak berkelanjutan sehingga membuat anak tidak bersungguhsungguh bahkan merasa ragu-ragu untuk melakukan suatu prilaku tertentu yang dipandang baik tersebut. Dalam keadaan ini pemberian contoh dan teladan guru yang terus menerus menjadi faktor sangat mendasar untuk pengembangan karaker siswa (Prasetyo \& Marzuki, 2016: 227). .

Dalam rentang waktu yang panjang, perilaku tersebut akan membentuk suatu pola budaya tertentu yang dinamakan kultur sekolah. Hal inilah yang pada akhirnya menjadi karakter khusus suatu lembaga pendidikan yang sekaligus menjadi pembeda dengan lembaga pendidikan lainnya. Masyarakat yang mayoritas berkarakter tidak baik, tidak mungkin mampu membangun peradaban, apalagi membangun peradaban yang tinggi (Aziz, 2009: 23). Suatu negara yang tidak dapat mempertahankan karakter yang baik akan kehilangan jati diri sebagai pribadi dan bangsa (Amin, 2013: 11). Oleh sebab itu pertaruhan mempertahan karakter bangsa adalah sesuatu yang sangat urgen. Jika ini terjadi, maka konsekuensinya adalah kita tidak akan mungkin bisa menghasilkan tatanan masyarakat madani yang diharapkan, malah mungkin sebaliknya, masyarakat kita di masa depan akan terjerumus menjadi masyarakat yang destruktif serta tidak mampu memberikan ciri masyarakat 
sebagai suatu bangsa yang berperadaban.

Kultur Sekolah merupakan budaya sekolah yang dapat memberikan pengaruh terhadap kehidupan masyarakat sekolah baik pengaruh positif maupun pengaruh negatif sebagaimana karakteristik kultur tersebut. Kultur sekolah terdiri dari kultur positif dan kultur negatif. Kultur positif adalah budaya yang membantu mutu sekolah dan mutu kehidupan bagi warganya (Murdiyanto, 2012). Dalam pengertian mutu sekolah dan mutu kehidupan dapat dimaksudkan sebagai mutu yang berhubungan dengan kehidupan yang bernilai moralitas dan agamis masyarakat sekolah. Aktifitas siswa dalam kesehariannya tidak akan lepas dari keterlibatan kultur sekolah pada proses bersikap, berbuat dan memandang bahkan berfikirnya.

Pendidikan karakter yang terimplementasikan pada setiap sekolah dan siswa, dan semua warga sekolah akan mampu membangun iklim sekolah yang mencerminkan kultur positif bagi kelangsungan lembaga pendidikan tersebut. Dengan kultur sekolah yang baik dari hasil penelitian yang dilakukan oleh Opata, Alfred \& Stephen (2017), disamping mampu memperbaiki hubungan antar personal sekolah juga mampu mendorong tumbuh persaingan yang baik. Di samping itu, kultur sekolah yang baik merupakan salah satu faktor yang dapat mendorong berkembangnya profesionalisme guru.

Berangkat dari analisis di atas, maka penelitian ini secara substantif diarahkan untuk mengetahui implementasi pendidikan karakter dalam membangun kultur sekolah pada Sekolah Dasar Negeri kabupaten Sambas. Kabupaten Sambas, dalam perpsektif sejarah merupakan kabupaten yang telah lama dikenal sebagai daerah yang memiliki perhatian tinggi terhadap nilai agama yang tentu menjadi pilar penting di dalam pendidikan karakter dan membangun kultur sekolah. Bahkan kabupaten ini pernah sangat dikenal dengan julukan "Serambi Mekkah", karena kuatnya pengaruh kehidupan beragama di dalam lingkungan masyarakat. Demikian pula kabupaten ini merupakan kabupaten yang memiliki sejumlah kecamatan yang berbatasan langsung dengan Negara tetangga Malaysia. Dalam keadaan ini pengembangan karakter siswa semakin diperlukan. Dalam Undang-undang Nomor 25 Tahun 2000 tentang Program Pembangunan Nasional (Propenas) diantara bagian di dalamnya menjelaskan pentingnya menjadikan wilayah perbatasan sebagai beranda depan negara melalui delimitasi dan demarkasi batas, pengamanan wilayah perbatasan dan pembangunan sosial ekonomi wilayah sepanjang perbatasan yang bermuara untuk menjaga keutuhan wilayah NKRI melalui penetapan hak kedaulatan NKRI yang dijamin oleh hukum internasional.

Atas dasar pemikiran dan faktafakta di atas maka penelitian ini difokuskan untuk menjawab beberapa dimensi mendasar, yaitu tentang program pendidikan karakter yang dirancang oleh sekolah, bentuk implementasi pendidikan karakter yang dilaksanakan oleh sekolah, evaluasi pelaksanaan pendidikan karakter yang dilaksanakan oleh sekolah dan wujud kultur sekolah yang terbangun dalam proses pembelajaran dan di luar proses pembelajaran.

\section{METODE PENELITIAN}

Penelitian ini menggunakan pendekatan kualitatif sebagai pendekatan utama, dan pendekatan kuantitatif sebagai pendukung. Pendekatan kuantitatif digunakan untuk mengkaji kultur sekolah, terutama untuk mengetahui dimensi-dimensi kutur dominan yang tubuh di lingkunagn sekolah. Sedangkan pendekatan kualitatif diarahkan untuk mengkaji 
secara detail tentang implementasi pendidikan karakter di dalam membangun kultur sekolah dalam satu kesatuan yang saling terkait, dan ini dinamakan juga inquiry naturalistic (Creswell, 1993: Sugiono, 2008: Aunurrahman, 2019). . Dengan demikian maka penelitian ini memadukan pendekatan kualitatif dan kuantitatif guna memperoleh kesimpulan yang lebih kaya dan obyektif terkait dengan implementasi pendidikan karakter dalam membangun budaya mutu di Sekolah Dasar kabupaten Sambas. Dengan demikian penelitian ini memadukan pendekatan kualiatif dan kuantitatif.

Subyek penelitian ini terdiri dari kepala Sekolah, guru-guru Sekolah Dasar Negeri dan pengawas sekolah. Sedangkan pengumpulan data dalam penelitian ini menggunakan teknik komunikasi langsung dan tidak langsung. Teknik komunikasi tidak langsung dilakukan dengan menggunakan kuesioner yang diisi oleh guru dan kepala sekolah terkait kultur sekolah. Sedangkan komunikasi langsung dilakukan melalui teknik wawancara dan diskusi kelompok terfokus (FGD) terhadap kepala-kepala sekolah dan sejumlah guru untuk menggali secara lebih detail informasi tentang implementasi pendidikan karakter dalam membangun kultur sekolah.

Data yang diperoleh melalui kuesioner akan dianalisis dengan menggunakan teknik analisis kuantitatif melalui penggunaan statistik Analisis faktor, dan persantase. Sedangkan data yang diperoleh melalui wawancara dan FGD akan dinalisis dengan teknik analisis kualitatif model Analisis Interaktif dari Miles dan Huberman.

\section{HASIL-HASIL PENELITIAN DAN PEMBAHASAN}

\section{Hasil-hasil Penelitian}

\section{a. Implementasi Pendidikan Karakter}

Sebagaimana pada bagian terdahulu sudah dikemukakan, bahwa untuk mengetahui implemnetasi pendidikan karakter dalam membangun kultur sekolah, maka analiais data dilakukan dengan menggunakan analisis kualitatif. Analisis kualitatif ini difokuskan pada penjabaran aspekaspek; program pendidikan karakter yang dirancang oleh sekolah, bentuk implementasi pendidikan karakter dan evaluasi pelaksanaan pendidikan karakter yang dilaksanakan oleh sekolah. Berikut disajikan hasil analisis berkenaan dengan tiga aspek utama implemnetasi pendidikan karakter tersebut.

\section{1). Perencaaan pendidikan karakter di sekolah}

Berdasarkan wawancara dan FGD dengan guru-guru, kepala sekolah dan pengawas diungkapkan bahwa secara keseluruhan semua sekolah sudah melaksanakan atau mengimplementasikan pendidikan karakter dalam berbagai aspek atau dimensinya. Namun jika dilihat dari perencanaan atau program tentang pendidikan karakter ini menurut informasi yang disampaikan memang kebanyakan sekolah belum menyusunnya secara sistematis. Kalaupun ada program penguatan pendidikan karakter di sekolah kami, ini semata-mata mengikuti kurikulum pendidikan yang ditetapkan pemerintah (Kurikulum 2013). Sedangkan yangterlibat adalah semua guru, siswa dan komite sekolah.

Bagi sejumlah sekolah yang sudah memiliki perencanaan atau program pendidikan karakter, berdasarkan informasi yang disampaikan proses penyusunannya dilakukan melalui rapat kepala sekolah beserta dewan guru. Biasanya yang terlibat adalah kepala sekolah, dewan 
guru komite sekolah dan orang tua siswa.

Meskipun pengembangan pendidikan karakter belum disusun dan dikembangkan dalam perencanaan atau program secara khusus, akan tetapi sesungguhnya kalu terkait dengan proses pembelajaran, guru-guru sudah mencantumkan dimensi-dimensi pengembangan karakter siswa di dalam rencana pembelajaran guru (RPP). Dengan demikian sebenarnya untuk pendidikan karakter yang menyatu dengan proses pembelajaran dengan sendirinya sudah dilakaukan secara terencana.

Di dalam proses penyusunan program pendidikan karakter (khusus bagi sekolah yang telah menyusun dan memiliki program), hal-hal yang menjadi pertimbangan sebagaimana disampaikan oleh beberapa guru dan kepala sekolah, antara lain; (1) kondisi lingkungan, (2) peserta didik, (3) orang tua.

\begin{tabular}{ccr} 
2). & \multicolumn{2}{c}{ Bentuk implementasi } \\
$\begin{array}{l}\text { pendidikan } \\
\text { dilaksanakan }\end{array}$ & karakter & yang \\
Dari & informasi & yang
\end{tabular}
disampaikan oleh guru-guru, kepala sekolah dan pengawas berkenaan dengan implementasi pendidikan karakter dapat dipilah ke dalam tiga dimensi pokok. Pertama, berkenaan dengan sosialisasi program pengembangan karakter oleh sekolah, khususnya kepada orang tua. Kedua, cara-cara yang yang dilakukan sekolah (guru-guru) agar siswa mengetahui peraturan dan tata tertib sekolah. Ketiga, bentuk-bentuk nyata dari kegiatan pengembangan karakter anak yang paling sering dilakukan.

Berkenaan dengan kegiatan sosialisasi program pendidikan karakter umumnya dilakukan dengan mengumpulkan oang tua siswa di sekolah dan menyampaikan kebijakankebijakan teknis sekolah yang terkait dengan pendidikan karakter anak.
Demikian pula sekaligus disampaikanhal-hal apa yang menjadi tanggung jawab orang tua di dalam upaya bersama-sama memelihara agar peserta didik dapat dibina dan dibimbing dengan sebaik-baiknya agar memiiki karakter yang diharapkan.

Adapun cara yang dilakukan sekolah agar para siswa mengetahui peraturan-peraturan, tata tertib atau kebiasaan-kebiasaan baik yang harus mereka ketahui dan lakukan, menurut informasi yang disampaikan oleh para guru, kepala sekolah dan pengawas antara lain dengan menempelkan aturanaturan tersebut pada papan pengumuman sekolah dan kelas. Di samping itu dilakukan dengan menginformasikan secara langsung kepada para siswa agar mereka memahami secara detail peraturan-peraturan tersebut beserta alasan-alasan perlunya melakukan atau mentaatinya.

Beberapa guru lain menambahkan bentuk-bentuk nayata dari pengembangan karakter anak yang paling sering atau yang menjadi penekanan dalam kegiatan keseharian di sekolah dan di kelas adalah;

a) Bersalaman dengan guru,

b) Terus menerus menjelaskan pentingnya kejujuran dan membiasakannya dalam aktivitas sehari-hari di kelas

c) Membiasakan untuk bertoleransi antara sesama siswa

d) Memberikan pemahaman tentang pentingnya cinta tanah air dan bangsa serta mencintai lingkungan

e) Membiasakan bertanggung jawab atas apapun yang ditugaskan atau dikerjakan

f) Membiasakan untuk suka menolong sesame

g) Menanamkan dan membaiasakan sikap religious

h) Membiasakan mandiri

i) Mendorong tumbuhnya rasa ingin tahu pada semua siswa

j) Menumbuhkan sikap kreatif. 


\section{3). Evaluasi terhadap program atau kegiatan-kegiatan pengembangan karakter siswa.}

Pada dimensi program pendidikan karakter, pendalaman data melalui wawancara dititikberatkan pada upaya penanganan terhadap siswa-siswa yang berperilaku tidak sebagaimana yang diharapkan dan pelaksanaan evaluasi pendidikan karakter dalam rangka menamin agar program pengembangan karakter siswa berlangsung secara berkelanjutan dan mencapai sasaran yang diharapkan.

Berkenaan dengan penanganan terhadap siswa-siswa yang belum dapat menyesuaikan perilaku dan tindakannya sesuai dengan aturan-aturan atau anjuran dari sekolah, mengacu pada sejulah pendapat yang disampaian oleh guruguru, kepala sekolah dan pengawas sekolah dasar cukup banyak yang mengatakan bahwa pertama-partama dipanggil untuk diberikan teguran dan nasehat-nasehat secara lisan. Pemberian nasehat ini tidak hanya dilakukan satu kali, akan tetapi dilakukan berkali-kali sambil memberikan pemahaman yang kongkrit dan mudah dimengerti oleh siswa tersebut. Akan tetapi bilamana sudah beberapa kali dipanggil dan dinasehati, masih nampak belum menunjukkan perubahan yang berarti, maka biasanya kita panggil orang tua. Bersama orang tua ini dilakukan tukar pikiran, dialog serta diskusi untukmengenali dan memahami lebih mendalam sebab-sebab siswa melakukan hal-hal tertentu. Biasanya ditemukan kesepakatan tentang apa yang harus ditindaklanjuti oleh sekolah dan apa yang perlu dilakukan oleh orang tua. Informasi yang lain juga disampaikan oleh beberapa orang guru berkenaan dengan tindakan yang dilakukan dalam menangani anak-anak yang belum menunjukkan sikap ataupun perilaku tidak seperti yang tertuang dalam aturan atau pembiasaan yang ditanamkan. Tindakan-tindakan tersebut dilakukan dalam bentuk;

a) Melakukan pendekatan kepada siswa

b) Bekerjasama dengan orang tua siswa yang bersangkutan

c) Memberikan teguran dan bimbingan kepada siswa

d) Memberikan sanksi bilamana dianggap perlu yang sifatnya mendidik.

Berkaitan dengan pelaksanaan evaluasi secara khusus terhadap implementasi program pendidikan karakter, sebagaimana disampaikan oleh guru-guru, kepala sekolah dan pengawas, hampir semuanya mengatakan bahwa sampai saat ini belum pernah dilakukan evaluasi secara khusus.

\section{b. Kultur Sekolah}

Untuk mengetahui kultur sekolah berdasarkan data yang dikumpulkan melalui kuesioner, selanjutnya dilakukan tahapan analisis dengan melakukan pengujian seluruh pertanyaan dengan menggunakan analisis faktor. Dari 19 pertanyaan yang disampaikan dan diisi oleh pengawas, kepala sekolah dan guru-guru hanya terdapat 12 faktor saja yang berpengaruh dari pelaksanaan atau implementasi pendidikan karakter. Dari 12 pertanyaan tersebut dibuat 3 faktor utama yang masing-masing mewakili dari 12 pertanyaan tersebut. Uji Kaiser-MeyerOlkin Measure dan Bartlett digunakan untuk mentukan langkah awal analisis faktor, dan kelayakan data. Berdasarkan nilai signifikansinya yaitu 0,000 dan kurang dari nilai alpha yaitu 0,05 maka dapat disimpulkan data tersebut layak untuk dianalisis faktor. Berikut disajikan hasil tes awal menggunakan KMO and Bartlett' Test sebagai berikut: 
Tabel 1. Hasil Test Awal Analisis Faktor

KMO and Bartlett's Test

\begin{tabular}{ll|r}
\hline Kaiser-Meyer-Olkin Measure of Sampling Adequacy. & .665 \\
\hline $\begin{array}{l}\text { Bartlett's Test of } \\
\text { Sphericity }\end{array}$ & Approx. Chi-Square & 152.715 \\
\cline { 2 - 3 } & df & 66 \\
\hline Sig. & .000 \\
\hline
\end{tabular}

Tabel diatas adalah untuk mentukan langkah awal analisis faktor, dimana layak tidaknya data yang akan dianalisis ditentukan dari uji KMO and Bartlett's ini. Dari nilai sig nya yaitu 0,000 dan kurang dari nilai alpha yaitu 0,05 dapat disimpulkan data tersebut layak untuk dianalisis dengan analisis faktor.

Selanjutnya untuk melihat hasil implemetasi pendidikan karakter dilakukan metode ekstraksi dengan Analisi Komponen Utama. Berdasarkan hasil uji yang dilakukan dengan pengintegrasian variabel yang tidak berpengaruh, maka terdapat 12 pertanyaan yang berpengaruh signifikan sebagai dampak darim implementasi pendidikan karakter. Hal ini dapat dilihat dari anti image correlation lebih dari 0,5 maka dapat disimpulkan nilai tersebut memiliki hubungan signifikan dengan pendidikan karakter.

Selanjutnya hasil perhitungan Analisis faktor dapat dilihat pada sajian gambar berikut Component Plot in Rotated Space

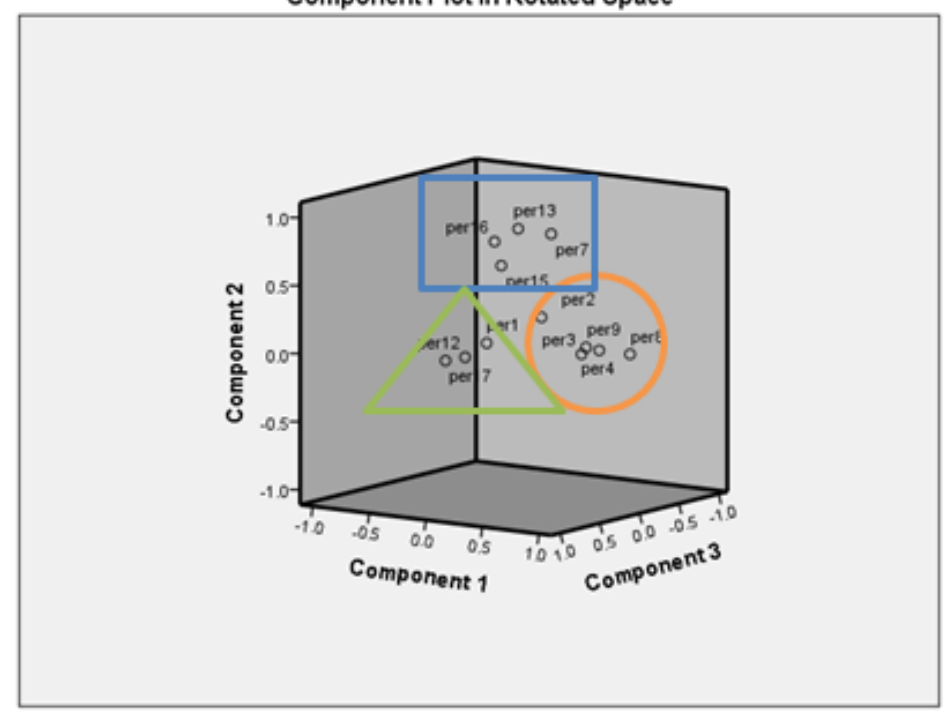

\section{Gambar 1.Hasil Analisis Faktor}

Gambar di atas merupakan bentuk pembagian dari faktor yang telah didapatkan dimana hasilnya adalah sebagai berikut.

Faktor 1 : per2, per3, per4,per8, per9 dimana kita sebut sebagai Faktor kultural disiplin. kontribusi pengaruh terbesar yang didapat adalah pada per9 yaitu sebesar $80,7 \%$ tehadapat implementasi pendidikan karakter. Yaitu guru memberikan contoh tiba disekolah lebih awal.

Faktor 2 : per7, per13, per15, per16 diamana kita sebut sebagai faktor kutural keteladanan. Yang memberikan kontribusi hubungan terbesar adalah per7 sebesar 80\% terhadapt implementasi pendidikan 
karakter. Yaitu mengadakan zuhur berjamaah

Faktor 3 : per1, per12, per17 dimana kita sebut sebagai faktor kutural ketertiban dan bersih. Yang memberikan kontribusi hubungan terbesar adalah per1 sebesar 68,9\% terhadap implementasi pendidikan karakter. Yaitu setiap senin sekolah mengadakan upacara.

Berdasarkan analisis faktor ternyata hanya ada 12 faktor atau pertanyaan yang memiliki pengaruh yang signifikan dari Implementasi pendidikan karakter. Dan ternyata dari 12 pertanyaan dapat dikerucutkan menjadi 3 faktor, yaitu (1) kultur disiplin dengan sumbangan item terbesar adalah memberikan contoh tiba di sekolah lebih awal, (2) kultur keteladanan dengan item pemberi sumbangan terbesar adalah mengadakan sholat Zyhur berjamaah,dan (3) kultur ketertiban dan kebersihan dengan sumbangan item terbesar adalah pelaksanaan upacara bendera setiap hari Senin.

\section{Pembahasan}

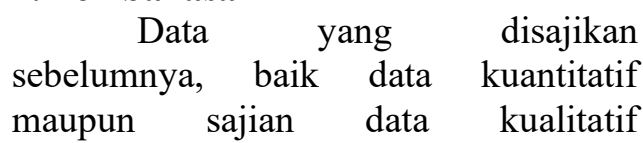
menunjukkan bahwa ada bagian-bagian dari kegiatan implemmentasi pendidikan karakter yang sudah dapat dapat dilaksanakan dan masih ditemukan juga bagian-bagian program dan kegiatan yang belum dapat dilakukan secara optimal. Demkian pula jika dilihat dari dimensi kultur sekolah terdapat rumpun kultur yang sudah tumbuh dengan baik atau tinggi, dan ada rumpun kulktur sekolah yang belum terbangun dengan optimal sebagai dampak langsung ataupun tidak langsung dari implementasi pendidikan karakter.

Dalam berbagai kajian diungkapkan bahwa penyusunan program pendidikan karakter dengan melibatkan berbagai unsur internal maupun eksternal sekolah merupakan bagian yang sangat penting, karena ketersediaan program merupakan tonggak mendasar agar kegiatankegiatan dapat dilaksanakan dan dikembangkan. Pada sisi lain programprogram atau perencanaan pendidikan karakter yang diketahui oleh guru-guru memberikan manfaat dan dampak yang sangat besar, baik dilihat dari dimensi guru-guru sendiri maupun dari dimensi sekolah. Bagi guru-guru, dengan mengetahui program ini akan memungkinkan semakin dalam pemahamannya tentang programprogram pendidikan karakter itu sendiri. Dalam mengimplementasikan pendidikan karakter dalam berbagai aspek yang ada di sekolah. Oleh sebab itu penting diupayakan penciptaan kondisi yang memungkinkan setiap orang, khususnya guru-guru dapat berpartisipasi khususnya di dalam penyusunan program pendidikan karakter ini. Sebagaimana hasil penelitian yang dilakukan oleh Revell \& Arthur (2007) mengungkapkan bahwa dari 1000 orang guru yang ada di dua universitas mengatakan bahwa mereka sangat mendukung upaya-upaya pengembangan karakter atau moral yang mereka peroleh dari universitas. Akan tetapi tidak semua mereka dapat mengembangkan karakter dan moral tersebut, karena akan sangat tergantung dari kondisi dan iklim sekolah tempat mereka bekerja.

Langkah awal perencanaan dalam menumbuhkan keikutsertaan guru-guru, orang tua dan pihak-pihak lain dalam penyusunan program dan implementasi pendidikan karakyer di sekolah adalah menanamkan kesadaran bersama dan menyamakan persepsi akan pentingnya suatu kegiatan yang ada pada semua aktivitas yang ada di sekolah atau lembaga pendidikan, sehingga nilai tersebut bisa menjadi habit (kebiasaan) oleh semua unsur yang ada di lembaga tersebut. Sejalan dengan 
pandangan yang dikemukakan oleh Hendriana dan Jacobus, (2015), bahwa pendidikan karakter berkaitan dengan ikhtiar atau proses pengubahan sifat, kejiwaan, akhlak, budi pekerti seseorang atau kelompok orang agar menjadi dewasa/manusia seutuhnya, insan kamil.

Dalam beberapa pembahasan diungkapkan bahwa setelah diperoleh kesamaan persepsi tentang pentingnya program penguatan pendidikan nilai/karakter, maka sekolah perlu menerjemahkan visi dan misi sekolah pada kerangka pendidikan karakter. Selanjutnya, kepala sekolah bersama dengan guru dan tenaga kependidikan serta masyarakat atau orang tua/wali siswa (komite) atau bahkan konselor harus melakukan langkah perencanaan:

(1) menentukan nilai karakter yang akan diterapkan di sekolah bersangkutan, (2) merancang program karakter terintegratif dengan semua mata pelajaran yang ada di madrasah, (3) merancang kondisi sekolah yang kondusif guna pelaksanaan pendidikan karakter, (4) merancang ruang kelas yang kondusif bagi pelaksanaan pendidikan karakter, (5) merancang lingkungan luar madrasah yang kondusif bagi pelaksanaan pendidikan karakter (Salim, 2015).

Berkenaan dengan implementasi pendidikan Dalam beberapa pembahasan diungkapkan bahwa setelah diperoleh kesamaan persepsi tentang pentingnya implemnetasi pendidikan karakter yang harus didukung oleh semua aunsur baik internal maupun eksternal sekolah. Tidak hanya guruguru yang dituntut memiliki komitmen dalam implementasi pendidikan karakter, akan tetapi yang utama justru orang tua siswa. Hal ini memang sering menjadi kendala disebabkan berbagai faktor. Wuryandani, dkk (2016: 208) mengungkapkan diantara kendala implementasi pendidikan karakter terutama karakter kemandirian antara lain (1) kurang konsistennya orang tua dalam mengikuti aturan-aturan sekolah untuk mengembangkan karakter siswa, (2) pada sisi yang lain sekolah belum mampu mengintegrasikan pendidikan karakter kemandirian secara komprehensif dalam proses pembelajaran di kelas.

Berkenaan dengan implementasi pendidikan karakter dalam membangun budaya sekolah sebagaimana telah dipaparkan sebelumnya menunjukkan, baik data kuantitatif maupun sajian data kualitatif menunjukkan bahwa ada dmensi-dimensi yang sudah terimplementasi dengan baik, akan tetapi juga diketahui ada bagian-bagian program dan kegiatan yang belum dapat dilakukan sebagaimana yang diharapkan.

Temuan-temuan penelitian berkenaan kultur sekolah yang telah dapat dikembangkan atau dibangun melalui implemnetasi pendidikan karakter sebagaimana telah dikemukakan sebelumnya menunjukkan bahwa; (1) pada faktor kultural disiplin, kontribusi pengaruh terbesar yang didapat adalah pada dimensi pemberian contoh oleh guru berkaitan dengan tiba disekolah lebih awal, (2) pada faktor kutural keteladanan, yang memberikan kontribusi hubungan terbesar adalah mengadakan zuhur berjamaah bersama siswa, (3) pada faktor kutur ketertiban dan bersih, yang memberikan kontribusi hubungan terbesar adalah setiap senin sekolah mengadakan upacara.

Pada kultur disiplin dimensi yang memegang peran terrpenting adalah pemberian contoh oleh guru kehadiran di sekolah lebih awal. Hal ini merupakan bagian yang sangat penting, karena baik di dalam implementasi pendidikan karakter maupun dilihat dari kultur sekolah, karena para siswa lebih mudah melihat secara langsung contoh yang diberikan oleh guru dibandingkan dengan ucapan-ucapan verbal yang 
sering di sampaikan oleh para guru. Dalam pembahasannya Kotter (2006:167) telah menegaskan gambaran tentang kultur dengan melihat dua lapisan, yaitu yang terlihat (bentuk fisik) dan tidak terlihat (nonfisik). Kultur inilah yang menjadi pembeda antara sekolah satu dengan lainnya. Dalam kaitan ini, hal-hal yang dapat dilihat secara langsung (fisik) akan mudah ditiru oleh siswa dalam wujud perilaku seharihari.

Berkenaan dengan pada faktor kutural keteladanan, yang memberikan kontribusi hubungan terbesar adalah mengadakan zuhur berjamaah bersama siswa adalah merupakan temuan yang sangat berarti di dalam mewujudkan kultur sekolah yang baik. Keteladanan yang diitunjukkan guru di hadapan siswa sangat besar nilainya karena siswa merasa bahwa guru tidak hanya bisa mengucapkan sesuatu yang baik, akan tetapi memang terwujud di dlam tindakan nyata sehari-hari. Hal ini akan memberi dampak bagi secara menyeluruh terhadap citra sekolah. Kultur sekolah memberikan gambaran tentang dinamika dan keadaan sekolah secara keseluruhan. Sebagaimana diungkapkan oleh Wang dan Zepeda (2013: 63), kultur sekolah menjadi salah satu daya tarik masyarakat atau konsumen pendidikan untuk menggunakan jasa pendidikan yang ditawarkan sekolah. Dalam keadaan ini, semakin baik atau positif kultur sekolah, maka akan semakin mendorong proses pembelajaran yang semakin baik serta sehat.

Hasil penelitian berkenaan dengan kultur sekolah khususnya pada faktor kutur ketertiban dan bersih, yang memberikan kontribusi hubungan terbesar adalah setiap senin sekolah mengadakan upacara. Pelaksanaan upcara terbukti menjadi bagian penting di dalam memberikan gambaran terhadap kultur sekolah yang baik. Hal ini disebabkan ada suasana atau iklim positif yang dirasakan oleh siswa tentang dinamika kehidupan sekolah ketika upacara berlangsung dengan baik, dimana semua orang bisa menunjukaan ketertiban, ketaatan pada aturan dalam satu kebersamaan di waktu yang sama. Dalam pandangan ini serng dikatakan bahwa kultur sekolah yang baik memungkinkan setiap warga sekolah akan mampu menginternalkan aturanaturan dari luar menjadi nilai-nilai pribadi yang dihidupi sampai pada taraf keteguhan dan kesetiaan. Dengan keteguhan, setiap orang akan konsisten mencapai hal-hal yang baik. Dan dengan kesetiaan, setiap warga sekolah akan mampu menghormati komitmen diri yang telah dipilih.

Dengan berjalannya kultur sekolah yang baik itu, kualitas kerja yang lebih baik akan terjamin. Jaringan dan komunikasi antar lini, baik sekolah dengan yayasan dan antar warga komunitas sekolah sendiri, akan terbuka. Kondisi ini tentunya akan merangsang keterbukaan dan transparansi pelaksanaan sistem persekolahan yang lebih baik. Kebersamaan dan rasa saling memiliki tentunya juga akan tercipta. Sejalan dengan itu, solidaritas dan rasa kekeluargaan akan tumbuh berbarengan dengannya. Tentunya, keadaan ini akan membuat warga sekolah menjadi lebih peka untuk cepat beradaptasi dengan perkembangan-perkembangan lain dari luar. Itu semua adalah fungsi dari kultur sekolah ketika nanti dapat berjalan dengan baik.

Pada akhirnya sekolah ada yang memiliki kultur kuat (strong) dan ada pula yang lemah (weak). Ketika warga sekolah, dari kepala sekolah hingga bagian kebersihan, memiliki komitmen yang tinggi terhadap nilai-nilai yang disepakati bersama maka sekolah tersebut memiliki kultur yang kuat (strong). Nilai kedisiplinan, misalnya, yang disepakati dan diterapkan bersama secara bertanggung jawab dan penuh komitmen maka sekolah tersebut 
memiliki kultur yang kuat. Sebaliknya, jika seluruh warga sekolah atau sebagian warga sekolah tidak memiliki komitmen terhadap implementasi nilai-nilai yang disepakati maka sekolah tersebut memiliki kultur organisasi yang lemah, dan pada akhirnya sulit bagi sekolah tersebut berkembang secara cepat dan mencapai prestasi sebagaimana diharapkan.

\section{KESIMPULAN DAN SARAN}

Berdasarkan analisis data yang dipaparkan pada bagian sebelumnya secara umum dapat disimpulkan bahwa implementasi pendidikan karakter dalam membangun kultur sekolah di Sekolah dasar Kabupaten Sambas dalam beberapa dimensi telah dilaksanakan. Namun pada bagian-bagian tertentu, khsususnya pada dimensi program dan evaluasi belum teraktualisasi dengan baik sesuai dengan yang diharapkan. Dalam pada itu, kultur sekolah secara keseluruhan sudah berkembang dengan baik terutama pada dimensi kultur disiplin, kultur keteladanan dan ketertiban.

Secara lebih spesifik mengacu pada rumusan masalah penelitian, berikut disampaikan simpulan-simpulan secara spesifik:

1. Pada dimensi program, hampir semua sekolah belum memiliki program pendidikan karakter yang komprehensif, sistematik dan spesifik. Kecuali perencanaan pendidikan karakter yang menyatu dengan Rencana Pembelajaran Guru (RPP) untuk implementasi pembelajaran di kelas, semua guru sudah membuat perencanaan sebagai bagian dari rencana pembelajaran secara keseluruhan.

2. Implementasi pendidikan karakter sudah dilaksanakan oleh semua sekolah dan telah melibatkan unsurunsur internal dan eksternal sekolah. Pelaksanaan pendidikan karakter diawali dengan sosialisasi. Meskipun sosialisasi ini belum dilakukan secara maksimal, akan tetapi pelaksaanaannya dilakukan dengan langkah-langkah sistematik dan ada upaya-upaya cukup intensif di dalam memelihara agar karakter siswa sudah baik dapat terpelihara.

3. Pada komponen evaluasi terlihat belum dilakukan secara maksimal dengan melibatkan berbagai pihak, terutama pihak eksternal sekolah. Belum tersedia program evaluasi untuk melihat sejauhmana implementasi pendidikan karakter dapat diaktualisaskan, sehingga belum dapat diindentifikasi secara kongkrit masalah-masalah dan kendala di dalam pelaksanaannya.

4. Berkenaan dengan wujud kultur sekolah yang terbangun dalam proses pembelajaran dan di luar proses pembelajaran dari hasil analisis temuannya dijabarkan dalam 3 dimensi pokok, yaitu; dimensi kultur kedisiplinan, dimensi kultur keteladanan dan dimensi tertib dan kebersihan.

Bedasarkan temuan penelitian dan simpulan di atas, disaran beberapa hal berikut:

1. Diperlukan langkah-langkah kongkrit sekolah, khususnya Kepala Sekolah untuk melibatkan semua unsur sekolah secara intensif di dalam menyusun program pendidikan karakter, termasuk unsur komite sekolah. Diharapkan dapat dilibatkan unsur masyarakat lainnya, seperti tokoh-tokoh masyarakat dan pemerintah, terutama pengawas sekolah dan Dinas Pendidikan.

2. Keteladaan guru-guru di dalam disiplin waktu datang ke sekolah memberi kontribusi terbesar bagi berkembangnya kultur sekolah. Oleh sebab itu diperlukan komitmen yang lebih tinggi dari kepala sekolah dan guru-guru untuk mempertahankan 
disiplin yang sudah terbangun dengan baik ini.

3. Evaluasi implementasi pendidikan karakter perlu disusun secara terprogram. Keterlibatan guru-guru perlu dioptimalisasi di dalam rangka menumbuhkan partisipasi dan komitmen untuk menjamin terlaksananya pendidikan karakter dan memelihara kultur sekolah yang kondusif.

\section{REFERENSSI}

Amin, Maswardi M. (2013). Pendidikan Karakter Anak Bangsa. Edisi Revisi. Jakarta: Baduose Media Jakarta.

Aunurrahman. (2019). Buku Ajar Penelitian Kualitatif \& Pengembangan. Memuat Konsepkonsep Praktis untuk Dosen dan Mahasiswa. Pontianak: Fahruna Bahagia.

Ayi, Suherman. (2018). The Implementation of Character Education Values In Integrated Physical Education Subject In Elementary School. Journal SHS Web of Conference. Journal Social Science. ISSN: 2261-2424 (Online).

Aziz, Samsudin. (2009). Karakter Pemuda Pilihan. Jakarta: RIMBOOKS.

Creswell, J. W. (1998). Qualitative Inquiry and Research Design Choosing Among Five Traditions. London, New Delhi: Sage Publications International Educational and Professional Publisher.

Fauzi. A, Zainuddin \& Rosyid. (2018). Penguatan Karakter Rasa Ingin Tahu dan Peduli Sosial Melalui
Discovery Learning. Jurnal Teori dan Praksis Pembelajaran IPS.2018;2(2):83-93. Issn: 25031201 , (Print); 2503-5347

(Online).

Kementerian Pendidikan Nasional. (2011. Pendidikan Budaya dan Karakter Bangsa. Jakarta: Direktorat Pembinaan SMA Kemendiknas.

Kotter, John P (2006). Leading Change. Boston: Harvard Business School Press.

Revell, Lynn \& James Arthur. 2007. Character education in schools and the education of teachers. Journal of Moral Education, vol 36, 2007 issue 1. Pages 79-92 Published online. : 13 Mar 2007. https://doi.org/10.1080/03057240 701194738 .

Maunah, Binti. (2015). Implementasi Pendidikan Karakter dalam Pembentukan Kepribadian Holistik Siswa. Jurnal Pendidikan Karakter Tahun V, Nomor 1, April 2015. ISSN. 2089-5003.

Mooerdiyanto. (2012). The Picture of Senior High School's Culture The Challenge and Opportunity. FISE Yogyakarta State University.

Opata, CN., Alfred S \& Stephen T. (2017). The Cultural School of Strategic Formulation (Strategy Formulation Based on Social Interactions, Beliefs and Traditions).

DOI: 10.4236/ojbm.2017.52029. PP. 335-347.

Prasetyo, Danang dan Marzuki. (2016). Pembinaan Karakter melalui Keteladanan Guru Pendidikan Kewarganegraan di Sekolah Islam Al Azhar Yogyakarta. Jurnal 
Pendidikan Karakter tahun VI, Nomor 2, April 2016. ISSN: 20189-50003.

Salimin, Ahmad. 2015. Manajemen pendidikan karakter di madrasah (Sebuah Konsep dan Penerapannya). Jurnal TARBAWI, Volume 1 Nomor 2, Juli - Desember 2015. ISSN: 2442-8809

Soedarsono, Soemarno. (2009). Karakter Mengantar Bangsa dari Gelap Menuju Terang. Jakarta: PT. Elex Media Komputindo.
Sugiono. (2008). Memahami Penelitian Kualitatif. Bandung: CV Alfabeta.

Zepeda, S. Wang, F. (2013). A Comparative Study of Two Schools: How School Cultures Interplay the Development of Teacher Leadership in Mainland China. Creative Education, 4, 63$68 . \quad$ doi: $10.4236 /$ ce.2013.49B013.

Wuryandani W, Faturrohman, Unik A. (2016). Implementasi Pendidikan Karakter Kemandirian di Muhammadiyah Boarding School. Cakrawala Pendidikan. Jurnal Ilmiah Pendidikan. Juni 2016, Th XXXV, No 2. Yogyakarta: LPPMP UNY. 